\title{
PENGEMBANGAN MODUL SEJARAH PERGERAKAN INDONESIA TERINTEGRASI NILAI KARAKTER RELIGIUS
}

\author{
Kuswono \\ Program Studi Pendidikan Sejarah FKIP Universitas Muhammadiyah Metro \\ Email: kromowijoyo@gmail.com
}

\section{Cahaya Khaeroni}

Program Studi Komunikasi Penyiaran Islam FAI Universitas Muhammadiyah Metro Email: c.khaeroni@gmail.com

\begin{abstract}
Abstrak
Penelitian ini bertujuan untuk menanalisis kebutuhan dalam mengembangkan modul pembelajaran sejarah terintegrasi nilai karakter religius. Modul yang dikembangkan menerapkan pembelajaran terintegrasi karakter keagamaan sehingga mampu peningkatan aspek kognitif dan afektif serta menumbuhkan perilaku yang sesuai dengan nilai-nilai islami. Penelitian ini menggunakan metode Research and development. Hasil penelitian menunjukan kurikulum yang sedang dikembangkan saat ini dimulai tahu (2015) adalah kurikulum perguruan tinggi (KPT) yang mengacu kerangka kualifikasi Nasional Indonesia (KKNI). Bahan ajar masih belum memuat poin-poin makna dari peristiwa (Ibrah). Diskusi yang dilakukan oleh mahasiswa hanya sampai pada pembahasan materi, sedangkan muatan nilai karakter yang terkandung dalam peristiwa tersebut belum mampu mereka sampaikan. Model modul menggunakan teori advan organizer. Modul dikembangkan dengan memasukan muatan nilai karakter islami dari peristiwa perkembangan Muhammadiyah tahun 1912-1923. Modul dilengkapi dengan latihan dan soal serta jawaban sehingga mahasiswa dapat mengukur kemampuannya sendiri. Hasil uji kelayakan modul tersebut menunjukan bahwa kualitas modul berada pada kriteria baik dengan rata-rata nilai 78 .

Kata kunci: Analisis Kebutuhan, Modul, Karakter, Religius.
\end{abstract}

\section{Abstract}

This study aims to menanalisis needs in developing learning modules integrated historical value religious character. Modules developed implementing integrated learning religious character so as to increase cognitive and affective aspects as well as foster appropriate behavior with Islamic values. Research method used in this research and development. The results showed that the curriculum is being developed today started out (in 2015) is the college curriculum (KPT), which refers to the Indonesian National qualifications framework (KKNI). Teaching materials are still not loading points the meaning of events (ibrah). Discussions undertaken by students only to the discussion of the material, while the value-laden character contained in the incident have not been able to convey. Models in the module that is taking advan theory organizer. The module was developed by entering a value-laden Islamic character of the events the Muhammadiyah development in 1912-1923. The module is equipped with exercises and questions and answers so that students can measure their own abilities. The test results show that our modules feasibility quality modules that are in both criteria with an average value of 78.

Keywords: Needs Analysis, Module, Character, Religious

PENDAHULUAN

\begin{tabular}{rrr} 
Pelaksanakan & \multicolumn{2}{r}{ pembelajaran } \\
membutuhkan & inovasi & yang
\end{tabular}

berkelanjutan. Inovasi itu dimaksudkan untuk menyesuaikan dengan tuntutan dan kebutuhan peserta didik. Peserta 
didik bukan lagi diibaratkan sebagai gelas kosong yang harus diisi air, melainkan manusia yang membutuhkan keterampilan hidup baik soft skills maupun hard skills. Maka pembelajaran kreatif dan inovatif seharusnya dilakukan oleh guru dalam upaya menghasilkan peserta didik yang kreatif. Tingkat keberhasilan guru dalam mengajar dilihat dari keberhasilan peserta didiknya sehingga dikatakan bahwa guru yang hebat (great teacher) itu adalah guru yang dapat memberikan inspirasi bagi peserta didiknya (Sani, Ridwan Abdullah, 2013).

Pengetahuan dan keterampilan mahasiswa harus diikuti dengan pembentukan sikap dan perilaku yang mencerminkan orang yang terpelajar. Hal ini perlu menjadi perhatian karena orang pintar yang tidak bermoral akan menjadi orang yang berbahaya bagi orang lain. Sikap yang perlu dibentuk melalui pembelajaran adalah: kejujuran, tanggungjawab, toleransi, keperdulian terhadap orang lain, kedisipilinan, santun, percaya diri, dan cinta damai (Sani, Ridwan Abdullah, 2013:44). Selain itu harus terdapat kemampuan yang lebih bagi mahasiswa calon pendidik karena selain menginternalisasi nilai karakter mahasiswa calon pendidikan harus mampu untuk mengimplementasikan atau menyampaikan nilai-nilai itu kepada siswa. Jika dianalogikan mahasiswa non keguruan itu sebagai "nabi” sedangkan mahasiswa keguruan (calon pendidik) adalah "rosul".

Faktor guru dalam pembelajaran sejarah menjadi hal yang penting untuk keberhasilan pembalajaran sejarah. Kompetensi guru sejarah SMA meliputi penguasaan bidang studi atau bahan ajar, pemahaman karakteristik peserta didik, penguasaan pengelolaan pembelajaran, penguasaan strategi dan metode pembalajaran, penguasaan penilaian hasil belajar siswa dan memiliki kepribadian dan wawasan pegembangan profesi (Aman, 2011). kinerja guru sejarah di kota Metro ratarata mencapai kategori baik dan sangat baik. Namun dari analisis yang telah dilakukan serta temuan-temuan dalam penelitian yang dilihat dari beberapa sub-variabel dan indikator kinerja guru maka terdapat beberapa hal yang menunjukan kelemahan-kelemahan kinerja guru sejarah. Variabel tersebut antara lain tentang evaluasi pembelajaran sejarah dan rata-rata guru belum mempunyai bahan ajar untuk mendukung terhadap implementasi pembelajaran sejarah berkarakter (Kuswono, 2015: 97).

Pendidikan karakter sebagai upaya yang disengaja dan terfokus untuk membantu siswa memahami, peduli dan bertindak berdasarkan nilai-nilai etis dan sebagai pengajaran siswa untuk kebaikan, mencintai hal yang baik, dan 
melakukan kebaikan. Karakter sebagai suatu ciri khas berkaitan erat dengan akhlak. Adanya istilah pendidikan karakter mengisyaratkan bahwa pengertian pendidikan mengalami pendangkalan makna. Tujuan pendidikan pada dasarnya adalah membentuk karakteryang baik dalam diri manusia sehingga akan tercapai masyarakat yang cerdas, dan berkarakter baik. Dengan demikian secara tersirat dalam pengertian pendidikan, telah memuat mengenai pendidikan karakter dengan menanamkan unsur pengetatrun (kognitif, nilai sikap (afektif, dan cara berperilaku (psikomotorik) kepada peserta didik (Kuswono, 2013: 43).

Saat ini hampir semua tulisan sejarah cenderung berpusat hanya pada fakta dari peristiwa tanpa banyak mengulas makna yang terkandung didalamnya. Sehingga gambaran sejarah yang muncul dalam benak peserta didik hanyalah menghafal fakta dan peristiwa sejarah tanpa mempunyai makna. Disamping itu, menyikapi pembelajaran sejarah yang mengedepankan pada aspek kognitif maka perlu adanya pengembangan penulisan sejarah Persyarikatan Muhammadiyah dengan nuansa baru, yakni penulisan sejarah Muhammadiyah yang diintegrasikan dengan nilainilai keislaman.

Visi Universitas Muhammadiyah Metro ingin mewujudkan lulusan yang mampu mengintegrasikan nilai-nilai keislaman dalam kompetensi yang dimiliki lulusan, dengan demikian perlu adanya impelementasi lebih untuk mencapai visi tersebut. Adapun salah satu fokus masalahnya adalah kelangkaan bahan ajar yang terintegrasi dengan nilai-nilai keislaman, masih kecil sekali bahan ajar yang telah mengintegrasikan materi ajar dengan nilai-nilai keislaman. Penelitian ini mencoba untuk mengembangkan modul ajar tentang sejarah Persyarikatan Muhammadiyah yang diintegrasikan dengan nilai-nilai keislaman. Manfaat yang ingin dicapai adalah menyokong tercapainya visi UM Metro dalam menciptakan lulusan yang memiliki kompetensi bersandar pada nilai-nilai religius. Pengembangan Modul terintegrasi nilai karakter menjadi perlu dan wajib sebagai kompetensi mahasiswa calon pendidik sehingga menicptakan generasi yang cerdas dari aspek kognitif, afektif dan psikomotorik.

Modul dalam Pembelajaran terdapat beberapa ahli yang memberikan definisi tentang modul, salah satunya pengertian modul yang dirumuskan oleh Mudlofir (2011) Bahan ajar (modul) adalah sebuah bahan ajar yang disusun secara sistematis, dan menarik yang meliputi materi ajar, metode dan evaluasi yang digunakan secara mandiri. Modul merupakan salah satu bahan ajar cetak yang disusun sedemikian rupa 
sehingga siswa dapat belajar secara individual.

Menurut Kunandar (2011) modul merupakan sebuah perangkat pembelajaran yang dikembangkan dari setiap kompetensi dan pokok bahasan yang akan disampaikan. Modul ini berisi materi, lembar kerja, lembar kegiatan siswa dan juga lembar jawaban siswa. Istilah modul dapat menunjuk pada suatu paket pengajaran yang memuat pedoman bagi guru dan bahan pembelajaran untuk siswa. Modul merupakan satuan program belajar-mengajar bagi siswa, yang dipelajari oleh siswa sendiri (selfinstructional). Menurut Nasution (2010) modul dapat dirumuskan sebagai suatu unit lengkap yang berdiri sendiri dan terdiri dari rangkaian kegiatan belajar yang disusun untuk membantu siswa mencapai tujuan yang telah dirumuskan secara khusus dan juga jelas.

Jadi modul ajar adalah satu unit program pembelajaran yang terencana, didesain untuk membantu peseta didik mencapai tujuan pembelajaran secara mandiri (self-intruction). Fungsi modul adalah mengatasi kelemahan pembelajaran tradisional, meningkatkan motivasi belajar, meningkatkan kreatifitas, mewujudkan prinsip maju berkelanjutan, mewujudkan belajar yang berkonsentrasi. Prinsip pengembangan modul yakni, berorientasi pada tujuan (goal oriented), pembelajaran mandiri (self-intruction), maju berkelanjutan (continuous progress), penataan materi secara modular yang utuh dan lengkap (self contained), rujuk silang antar modul, penilaian mandiri.

Pembelajaran menggunakan modul, secara efektif akan dapat mengubah persepsi siswa menuju konsep ilmiah, sehingga pada gilirannya hasil belajar mereka dapat ditingkatkan seoptimal mungkin baik dari segi kualitas maupun kuantitasnya. Modul ajar mempunyai beberapa format diantaranya mengandung tinjauan mata latihan, sajian materi yang terdiri dari pendahuluan, kegiatan belajar, rangkuman, tes formatif, kunci jawaban tes formatif glosarium, daftar pustaka (Mardiansyah, 2013).

Prinsip Pembuatan Modul menurut Sabri (2007) karakteristik pembelajaran dengan modul memiliki prinsip fleksibilitas, yakni prinsip menyesuaikan perbedaan siswa; Prinsip feed-back; Prinsip penguasaan tuntas (mastery learning), artinya siswa belajar tuntas; Prinsip remidial, memberikan kesempatan kepada siswa untuk memperbaiki kesalahan atau kekurangannya; Prinsip motivasi dan kerjasama; Prinsip pengayaan. Bahan ajar berupa modul memungkinkan siswa untuk dapat belajar secara mandiri. Modul dalam pembelajaran bermanfaat dalam efektivitas waktu untuk mencapai kompetensi yang telah ditetapkan. Modul minimal tersusun atas pendahuluan, 
pembelajaran, dan evaluasi (Mardiansyah, 2013).

Modul yang dibuat tidak sekedar mennyajikan materi namun dilengkapi dengan nilai-nilai karakter yang terkandung dalam peristiwa sejarah yang dibahas. Pendidikan karakter dalam Islam identik dengan akhlak. Akhlak adalah watak, tabiat, pembawaan. Menurut Al-Ghazali akhlak adalah suatu sifat yang tetap pada jiwa yang memungkinkan seseorang melakukan perbuatan-perbuatan dengan mudah dan seketika (Marzuki, 2010). Secara definitif akhlak menunjuk pada sifat-sifat alami yang lurus dan teratur serta sifat-sifat yang diupayakan terjadi, tercipta bersama wataknya. Akhlak tidak sematamata terwujud pada perilaku secara lahiriah saja melainkan mencakup sikap batin ketika melakukan perilaku tersebut (Marzuki, 2015). Sedangkan pengertian karakter adalah jati diri, kepribadian, dan watak yang melekat pada diri seseorang. Karakter selalu berkaitan dengan dimensi fisik dan psikis individu. Karakter bersifat kontekstual dan kultural (Gufron, 2010). Karakter merupakan keseluruhan disposisi kodrati dan disposisi yang telah dikuasai secara stabil yang mendefinisikan seorang individu dalam keseluruhan tata perilaku psikisnya yang menjadikannya tipikal dalam cara berpikir dan bertindak. Dengan demikian konsep karakter dengan konsep akhlak mempunyai kesamaan pengertian.

$$
\text { Sejak } 2010 \quad \text { Indonesia }
$$

menggalakan tentang pendidikan karakter bangsa pendidikan karakater dapat diartikan sebagai upaya yang dirancang secara sistematis dan berkesinambungan untuk membentuk kepribadian peserta didik agar memiliki pengetahuan, perasaan, dan tindakan yang berlandaskan pada norma-norma luhur yang berlaku di masyarakat (Triatmanto, 2010). Pendidikan karakter secara terintegrasi di dalam pembelajaran dilakukan dengan pengenalan nilai-nilai, memfasilitasi diperolehnya kesadaran akan pentingnya nilai-nilai, dan penginternalisasian nilainilai ke dalam tingkahlaku peserta didik sehari-hari melalui proses pembelajaran, baik yang berlangsung di dalam maupun di luar kelas pada semua mata pelajaran. Pada dasarnya kegiatan pembelajaran, selain untuk menjadikan peserta didik menguasai kompetensi (materi) yang ditargetkan, juga dirancang untuk menjadikan peserta didik mengenal, menyadari/ peduli, dan menginternalisasi nilai-nilai dan menjadikannya perilaku. Integrasi dapat dilakukan dalam substansi materi, pendekatan dan metode pembelajaran, serta model evaluasi yang dikembangkan. Tidak semua substansi materi pelajaran cocok untuk semua karakter yang akan dikembangkan, perlu 
dilakukan seleksi materi dan sinkronisasi dengan karakter yang akan dikembangkan (Triatmanto, 2010).

Pada prinsipnya semua mata pelajaran dapat digunakan sebagai alat untuk mengembangkan semua karakter peserta didik pengintegrasian pendidikan karakter dalam perkuliahan dapat dilakukan dengan memasukkan nilai-nilai karakter dalam perencanaan (silabus dan RPP), bahan ajar dan media, implementasi di kelas, penilaian, monitoring, dan evaluasi kegiatan secara keseluruhan (Winarni, 2013).

Bahan ajar berbasis karakter adalah bahan ajar yang menyajikan materi ajar yang dilengkapi dengan nilainilai karakter sehingga siswa mampu memahami, menentukan sikap, dan berperilaku sesuai dengan bahan ajar tersebut. Bahan ajar berbasis karakter berfungsi sebagai alat untuk membantu dalam mencapai kompetensi, membentuk karakter, alat ukur penilaian berbasis karakter.

Sementara itu mengenai definisi sejarah begitu banyak dikemukakan oleh para ahli namun kesemuanya mengerucut pada kesimpulan bahwa sejarah adalah kisah dari peristiwa masa lalu yang dikemas berdasarkan data dan fakta yang didapatkan kemudian disajikan secara utuh. Sehingga sejarah akan mampu menjadikan manusia menjadi bijak dalam mengambil keputusan-keputusan hidup.
Sejarah menurut Edward Hallet Carr (2014: 35) dalam bukunya, What is History menyebutkan Sejarah adalah proses interaksi yang berlangsung secara terus-menerus antara sejarahwan dan fakta-fakta, yang menggabungkan antara sekarang dan masa lampau sebagai sbuah dialog yang tidak ada henti-hentinya. Lain halnya dengan Renier (1997: 81) yang mengatakan bahwa sejarah adalah cerita mengenai pengalaman orang yang berada didalam masyarakat yang beradab. Menurut Leopald Von Ranke bahwa pengertian sejarah adalah apa yang sungguh-sungguh terjadi (Von Ranke, L., \& Humboldt, W. 1973). Sementara menurut R. G. Collingwood (1993) adalah sebuah bentuk penyelidikan tentang hal-hal yang telah dilakukan oleh manusia pada masa lampau.

Menurut Roeslan Abdulgani sejarah adalah salah satu bidang ilmu yang meneliti dan menyelidiki secara sistematis keseluruhan perkembangan masyarakat serta kemanusiaan dimasa lampau, besarta segala kejadiankejadiannya dengan maksud untuk kemudian menilai secara kritis seluruh hasil penelitian dan penyelidikan tersebut, untuk ahirnya dijadikan sebagai perbendaharaan pedoman bagi penilaian dan penentuan keadaan sekarang serta arah program masa depan (Abd Rahman Hamid \& M. Saleh Majid, 2011: 8). Sedangan R. M. Ali 
mendefinisikan sejarah sebagai keseluruhan perubahan, dan kejadiankejadian yang benar-benar telah terjadi. Sejarah adalah ilmu yang menyelidiki perubahan-perubahan yang benar-benar terjadi di masa lampau (Abd Rahman Hamid \& M. Saleh Majid, 2011: 7)

Mengungkap peristiwa yang telah lalu merupakan sebuah tugas sejarawan yang membutuhkan proses panjang yang cukup melahkan. Bagaimana tidak, peristiwa yang telah berlalu harus kembali tercipta dimasa kini dengan bukti dan sumber pendukung seadanya. Ibaratnya menyusun kembali sebuah gelas yang pecah di atas lantai kemungkinan sebagian serpihannya berserakan ada yang hilang, tidak ditemukan lagi. Tentu kita butuh kerja keras dan cerdas untuk mengembalikan bentuk gelas itu secara utuh. Keruwetan dalam menyusun sejarah ini tetap harus tersajikan setidaknya membantu agar identitas suatu lembaga, manusia, negara dan lainnya tidak hilang ditelan waktu.

Menurut Kuntowijoyo (2005: 1935), Sartini (2011:59) Sejarah mempunyai kegunaaan intrinsik dan ekstrinsik. Secara instrinsik belajar sejarah memiliki 4 manfaat yaitu sebagai ilmu, cara mengetahui masa lampau, pernyataan pendapat dan sejarah sebagai profesi. Sedangkan kegunaan sejarah secara eksterinsik yaitu mempunyai fungsi pendidik, yaitu pendidikan moral; pendidikan penalaran; pendidikan politik; pendidikan kebijakan; pendidikan perubahan; pendidikan masa depan; pendidikan keindahan; ilmu Bantu; latar belakang; rujukan dan bukti.

Sejarah bagi suatu lembaga menjadi penting sebagai bagian dari jati diri yang menjadi gambaran untuk melangkah kemasa yang akan datang. Sam Wineburg (2006) mengatakan bahwa sejarah mempunyai peran dalam menetakan masa depan suatu lembaga dan mengajarkan berbagai hal dari masa lalu. Dengan sejarah pula suatu lembaga dapat mengambil suatu pilihan, mempertimbangkan program, dan mengingatkan untuk menjaga kewaspadaan. Sebuah lembaga tentunya tidak ingin mengalami suatu kesalahan yang terulang sedangkan keberhasilan yang telah diraih tentu ingin terus dicontoh. Sejarah suatu lembaga dapat dimanfaatkan sebagai inspitarif bagi lembaga tersebut dan bagi pembaca, sehingga akan memunculkan ide-ide atau action baru sebagai hasil koreksi atau tindak lanjut program terdahulu. Pada akhirnya tidak diragukan lagi bahwa belajar dari sejarah akan menggiring lembaga bahkan dunia kepada situasi yang serba unggul, tertata dan bermartabat.

\section{METODE PENELITIAN}

$$
\text { Metode penelitian ini }
$$

menggunakan metode penelitian dan 
pengembangan (Research and Development) Model ADDIE (Analisis, Design, Development, Implementation, Evaluation) dengan langkah-langkah yakni sebagai berikut.

1. Analisis kebutuhan (studi pendahuluan), dengan tujuan mengumpulkan berbagai informasi dari lapangan dan melakukan studi literatur yang dapat digunakan sebagai bahan untuk perencanaan produk yang diharapkan dapat mengatasi masalah.

2. Merancang produk, bagian ini akan merancang model bahan ajar (modul) terdiri dari perancangan kompetensi umum, kompetensi khusus, tujuan perkuliahan, indikator pembelajaran, dan akan menghasilkan rancangan modul untuk dikembangkan.

3. Pengembangan produk, setelah melakukan analisis kebutuhan dan desain produk maka akan dikembangkan model bahan ajar (modul) dengan menggunakan metode historis dengan mengintegrasikan nilai-nilai keislaman sebagai pemaknaan yang terkandung dalam materi ajar. Metode historis meliputi pengumpulan sumber (heuristik), verifikasi (kritik sumber dan keabsahan sumber), interpretasi (analisis dan sintesis), yang terakhir adalah penulisan.

4. Melakukan validasi desain produk. Validasi desain merupakan proses kegiatan untuk menilai apakah rancangan produk, dalam hal ini sistem kerja baru secara rasional akan lebih efektif dari yang lama atau tidak. Kelemahan dalam desain ditemukan dalam penelitian, sehingga perbaikan desain sebagai langkah lanjutan berikutnya. Validasi melalui diskusi dengan teman sejawat, pakar/ ahli keilmuan, dan mahasiswa sejarah.

5. Ujicoba produk untuk mengetahui kelayakan modul ajar. Dalam hal ini produk hanya akan di ujicobakan sampai pada ujicoba terbatas dengan skala kecil dalam lingkup mahasiswa pendidikan sejarah Universitas Muhammadiyah Metro.

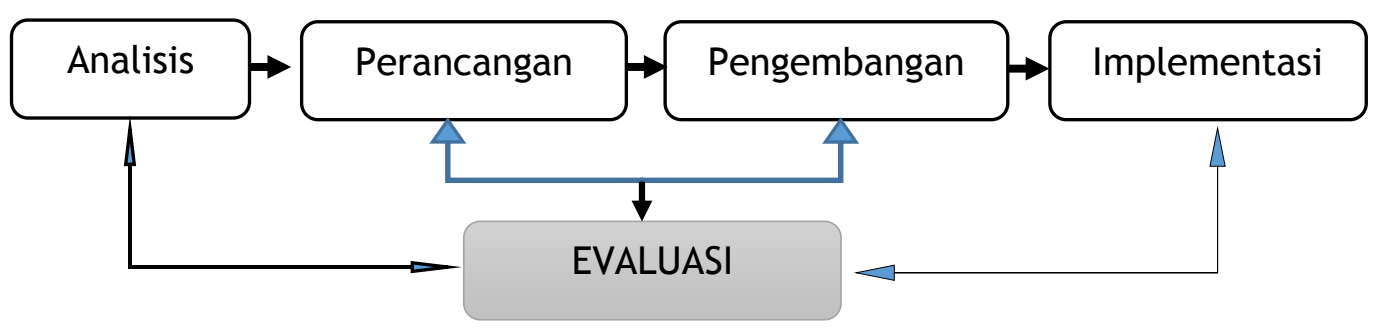

Gambar 1. Desain Penelitian dan Pengembangan Model ADDIE 
HASIL DAN PEMBAHASAN

Profil Program Studi Pendidikan Sejarah

Model yang digunakan dalam penelitian pengembangan ini adalah pengembangan model ADDIE (Analisis, Design, Development, Implementation, Evaluation) dengan langkah-langkah yakni analisis kebutuhan dan merancang modul seperti yang telah dilakukan diatas.

Pendidikan sejarah FKIP UM Metro secara resmi berdiri pada 5 Oktober 1989 dengan Nomor SK 0666/0/1989 yang ditandatangai oleh Menteri Pendidikan dan Kebudayaan RI. Dimulainya Penyelenggaraan program studi pendidikan sejarah FKIP UM Metro yakni pada Agustus 1983. Pendidikan Sejarah FKIP UM Metro mempunyai visi Mewujudkan pendidikan sejarah yang unggul dalam menciptakan tenaga pendidik di bidang sejarah, Berkarakter islami dan menguasi ipteks serta menjadi program studi pendidikan sejarah terbaik di Lampung tahun 2025.

Program Studi Pendidikan Sejarah FKIP UM Metro memiliki dua Profil lulusan dan satu profil pendukung. Pertama, sebagai calon guru (pendidik ) sejarah yang kompetensi dalam merencanakan, melaksanakan, dan mengevaluasi proses pembelajaran sejarah serta pembimbingan dalam mencapai tujuan pembelajaran sejarah (merujuk pada definisi Pendidik dalam UU No. 20 Tahun
2003 dan definisi Guru dalam UU No. 14 Tahun 2005). Kedua, sebagai peneliti pemula, yang memiliki kompetensi dalam membantu merencanakan penelitian, membantu atau melakukan kegiatan penelitian sendiri di bawah bimbingan, dan menyebarluaskan hasil penelitian dalam bidang Pendidikan Sejarah (Rujukan: Deskripsi Jenjang Jabatan Peneliti, setara Asisten Peneliti Muda/IIla). Sedangkan profil pedukung yang diunggulkan di pendidikan sejarah UM Metro adalah mahasiswa memiliki kompetensi sebagai parktisi pariwisata sejarah dan budaya, lebih jauh dapat memngembangkan history-preneurship, Pelaksana dalam dunia industri kepariwisataan khususnya wisata sejarah, yang menguasai pengetahuan tentang obyek-obyek wisata sejarah baik secara umum ataupun khusus (obyek wisata sejarah di Lampung) serta terampil dalam memimpin dan mengelola perjalanan wisata sejarah. Di Prodi Pendidikan Sejarah UM Metro terdapat laboratorium sejarah yang dapat digunakan sebagai pendukung pembelajaran yang cukup efektif. Koleksi yang dimiliki oleh laboratorium cukup lengkap terutama untuk sejarah Indonesia masaya purba dan sejarah Indonesia masa kemerdekaan.

Berdasarkan capaian kompetensi kurikulum yang dimiliki Program Studi Pendidikan Sejarah FKIP UM Metro menyesuaikan dengan rambu-rambu 
Kurikulum Pendidikan Tinggi (KPT) yang mengacu KKNI. Beban studi dalam kurikulum untuk KPT di Pendidikan Sejarah sebanyak 148 sks sehingga waktu perkuliahan bisa diselesaikan antara 7 sampai dengan 8 semester. KPT mulai di terapkan pada tahun akademik 2016/2017 untuk semester pertama, sedangkan semester diatasnya masih tetap menggunakan kurikuum lama dengan beban sks cukup banyak yakni 160 sks (Dokumen Kurikulum Pendidikan Tinggi Program Studi Pendidikan Sejarah FKIP UM Metro, 2015).

Bahan kajian yang tertuang dalam kurikulum yakni dasar-dasar kependidikan, pembelajaran sejarah, dasar-dasar ilmu sejarah, sejarah kawasan, sejarah tematik, teori-teori sosial, metode penelitian, studi lapangan dalam hal ini dinamai Studi Objek Sejarah (SOS), kajian kepariwisataan, magang kependidikan, KKN pendidikan, kajian keperiwisataan, al-Isam dan Kemuhammadiayahan sebagai ciri khas universitas di bawah naungan Muhammadiyah (Dokumen Program Studi Pendidikan Sejarah FKIP UM Metro, 2016).

$\begin{array}{ccc}\text { Proses } & \text { perkuliahan } & \text { yang } \\ \text { dilaksanakan } & \text { oleh program } & \text { studi }\end{array}$
pendidikan sejarah cukup baik. Hal ini berdasar pada penilaian yang diberikan oleh mahasiswa kepada dosen pengampu mata kuliah yang cenderung tinggi (rekapitulasi EDOM, 2016). Terdapat hal- hal yang masih menjadi tantangan dalam proses peruliahan yakni:

1. belum terciptanya suasana akademis di lingkungan kampus sehingga cukup berpengaruh terhadap minat belajar;

2. referensi pendukung untuk matakuliah di prodi pendidikan sejarah sudah cukup mumpuni, namun belum ada bahan ajar yang secara eksplisit mengandung nilainilai karakter di dalamnya;

3. Berdasarkan hasil wawancara dengan Ukar Noviansyah mahasiswa pendidikan sejarah ketua angkatan 2014 dapat diambil dari kesimpulan bahwa mahasiswa masih sulit untuk mengkaitkan atau memaknai antara peristiwa tekstual yang dipelajari dengan nilai-nilai karakter yang terkandung dalam kisah sejarah yang mereka dapatkan pada perkuliahan;

4. Para pengampu mata kuliah masih terpaku pada bahan ajar karya orang lain dan belum ada bahan ajar atau yang sejenisnya buatan dosen sendiri;

5. Perkuliahan masih mengandalkan tatap muka dan kecendrungan mahasiswa hanya belajar dari dosennya saja.

Dengan kasus tersebut maka pembuatan modul ini menjadi sangat penting sehingga nantinya akan memudahkan pengampu maupun 
mahasiswa dalam mendalami

perkuliahan sejarah.

Model Modul Bermuatan Nilai-Nilai keIslaman

Model modul yang dilembangakan yakni mengacu pada standar pembuatan modul miliki universitas terbuka. Modul Universitas Terbuka menjadi rujukan karena pernah dinobatkan sebagi modul yang paling baik dalam proses perkuliahan. Pengembangan Modul didahului dengan pembuatan instrumen penilaian kelayakan modul. Instrumen kelayakan modul terbagi menjadi dua yakni kelayakan isi dan desain. Instrument tersebut dimodifikasi dari instrument pengambangan modul yang dikembangkan oleh kemendiknas tahun 2015. Pembuatan modul dilakukan menjadi beberapa tahapan yakni:

1. Menentukan tema materi yang akan dibuat modul. Materi yang dikembangan menjadi modul adalah sejarah persyarikatan Muhammadiyah dengan mengambil sub judul yakni perkembangan Muhammadiyah dari awal berdiri tahun 1912 sampai dengan tahun 1923. Batasan pembahasan itu supaya materi bisa lebih focus dan mendalam;

2. Model dalam modul tersebut yakni mengambil teori advan organizer dengan memberikan penjelasan secara ringkas diawal pembahasan sehingga mahasiswa akan lebih cepat memahami isi dari modul tersebut;

3. Modul dikembangkan dengan memasukan muatan nilai karakter islami dari peristiwa perkembangan muhammadiyah;

4. Modul dilengkapi dengan latihan dan soal serta jawaban sehingga mahasiswa dapat mengukur kemampuannya sendiri.

\section{Penyusunan dan Uji Kelayakan Modul}

Materi modul Sejarah

Persyarikatan Muhammadiyah 1912-1923

Terdiri dari 3 kegiatan belajar yakni Kegiatan belajar pertama, Munculnya gerakan pemurnian ajaran Islam; Kegiatan belajar kedua, Ahmad Dahlan: Intelektual Pemurnian Islam Indonesia; Kegiatan belajar ketiga, Membangun Semangat al-Maun.

Di atas telah disebutkan hasil dari Analisis kebutuhan (studi pendahuluan) yakni masih belum adanya modul yang secara eksplisit mengintegrasikan nilai karakter religius. Kemudian dilakukan perancangan produk dengan memperhatikan hasil temuan dari analisis kebutuhan. Merancang model modul dilakukan dengan memilih mata kuliah yang akan dibuat modul. Matakuliah tersebut adalah Sejarah Pergerakan Indonesia dengan beban 2 sks dan diambil pada semester gasal. 
Setelah penentuan mata kuliah maka dipilih materi yang cocok dan lebih menjiwai dengan nilai karakter religius. Melalui diskusi terbatas maka diputuskan untuk mengambil materi mengenai sejarah pergerakan Muhammadiyah kompetensi khusus yang ingin dicapai adalah mahasiswa mampu menganalisis latarbelakang, pola pergerakan Muhammadiyah kemudian menyimpulkan dengan mengambil nilai-nilai karakter dari peristiwa tersebut.

Pengembangan produk, setelah penentuan materi maka penelitian dilanjutkan dengan mendesain produk berupa model bahan ajar (modul) dengan menggunakan metode historis dengan mengintegrasikan nilai-nilai keislaman sebagai pemaknaan yang terkandung dalam materi ajar. Metode historis meliputi pengumpulan sumber (heuristik), verifikasi (kritik sumber dan keabsahan sumber), interpretasi (analisis dan sintesis), yang terakhir adalah penulisan. Setelah draft modul tersusun maka penelitian fokus pada penentuan nilai karakter religius sebagai ciri khas pada modul ini.

Melakukan validasi desain produk. Validasi desain merupakan proses kegiatan untuk menilai apakah rancangan produk, dalam hal ini sistem kerja baru secara rasional akan lebih efektif dari yang lama atau tidak. Kelemahan dalam desain ditemukan dalam penelitian, sehingga perbaikan desain sebagai langkah lanjutan berikutnya. Validasi melalui diskusi dengan teman sejawat, pakar/ ahli keilmuan, dan mahasiswa sejarah. Dalam hal ini terdapat beberapa masukan yakni mengenai munculnya model advance organizer sebagai penambahan dari validator. Dari segi bahasa validator masih menyangsikan karena banyak tulisan yang salah ketik. Bahasa belum menunjukan sebuah modul yang komunikatif. Begitu juga jenis huruf semula digunakan time new roman menjadi sorotan. Jenis huruf ini sulit dibaca dibandingkan dengan beberapa jenis huruf lainnya. Revisi dilakukan berdasar masukan validator. Jenis huruf diubah menjadi Trebuchete Ms. Sampul modul diubah dengan tema kemuhammadiyahan.

Ujicoba produk untuk mengetahui kelayakan modul ajar. Dalam hal ini produk hanya diujicobakan sampai pada ujicoba terbatas dengan skala kecil dalam lingkup mahasiswa pendidikan sejarah Universitas Muhammadiyah Metro. Terdapat 5 aspek yang dievaluasi dari hasil pengembangan ini yakni 1 . aspek kelayakan isi; 2. aspek kelayakan penyajian; 3 . aspek penilaian kontekstual; 4. aspek penilaian tampilan; 5. aspek penilaian kebahasaan. Hasil dari ujicoba tersebut adalah sebagai berikut dibawah ini. 


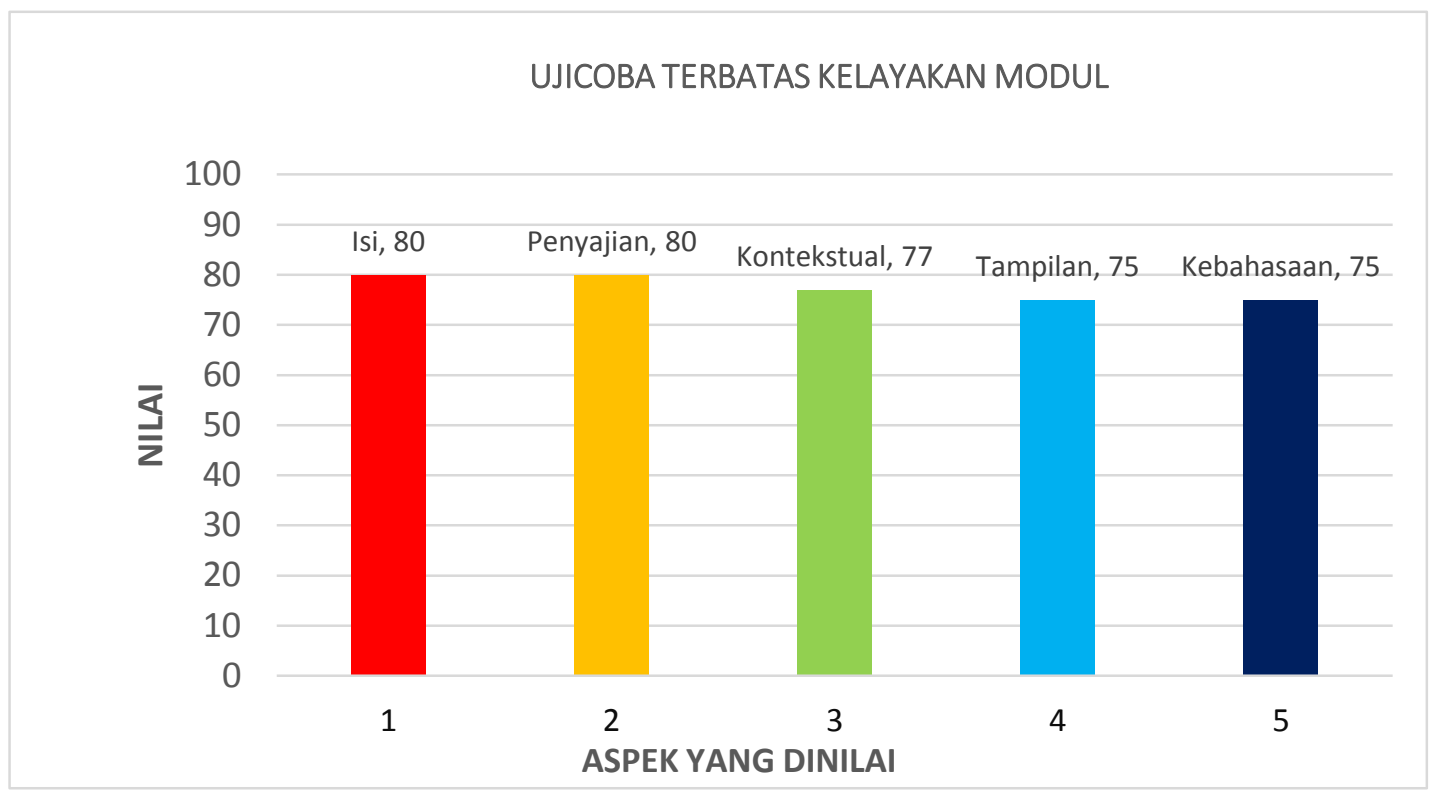

Gambar 2. Hasil penilaian kelayakan modul oleh pengguna

Pelaksanaan uji kelayakan modul dilakukan kepada mahasiswa sebanyak 40 mahasiswa. Dilihat dari hasil tersebut diatas terlihat jelas bahwa aspek tampilan dan kebahasaan masih rendah dibandingkan dengan nilai yang lainnya. Kedua aspek tersebut perlu diperbaiki, aspek tampilan akan menjadi daya tarik pertama ketika pembaca melihat modul tersebut. Tampilan mencakup desain sampul tata letak tulisan serta gambar yang terdapat pada modul. Sampul dibuat lebih mencirikan pada Muhammadiyah sehingga terdapat gambar lambang Persyarikatan Muhammadiyah dan foto Kh. Ahmad Dahlan. Sedangkan kebahasaan perlu diperbaiki menjadi lebih lugas dan tertata. Dari komentar responden kebanyakan masih merasa sulit memahami konteks dalam modul tersebut sehingga responden menyarankan agar bahasa diperbaiki.

\section{PENUTUP}

\section{Kesimpulan}

Inovasi pembelajaran mempunyai peran penting dalam usaha memajukan pendidikan di Indonesia. Salah satu inovasi yang dilakukan adalah melakukan pengembangan model dalam bahan ajar (modul). Modul yang dikembangkan mengambil teori advan organizer dengan memberikan penjelasan secara ringkas diawal pembahasan sehingga mahasiswa akan lebih cepat memahami isi dari modul tersebut. Modul dikembangkan dengan memasukan muatan nilai karakter islami dari sejarah perkembangan Muhammadiyah. Terdapat 5 aspek yang dievaluasi dari hasil pengembangan ini yakni aspek kelayakan isi; aspek kelayakan 
penyajian; aspek penilaian kontekstual; aspek penilaian tampilan; aspek penilaian kebahasaan. Hasil uji kelayakan modul tersebut menunjukan bahwa kualitas modul berada pada kriteria baik dengan rata-rata nilai 78 .

\section{DAFTAR PUSTAKA}

Carr. E.H. (2014). Apa Itu Sejarah. Jakarta: Komunitas Bambu.

Collingwood, R. G., \& van der Dussen, W. J. (1993). The idea of history. Oxford University Presson Demand.

Hamid, A. R., \& Madjid, M. S. (2011). Pengantar Ilmu Sejarah. Yogyakarta: Ombak.

Kunandar. (2011). Menjadi guru Profesional. Bandung: Rosdakarya

Kuntowijoyo. (1995). Pengantar Ilmu Sejarah. Yogyakarta: Bentang.

Kuswono, K. (2013). Character Education Muhammadiyah Pattern (Case Study SMA Muhammadiyah 1 and MA Muallimin Yogyakarta). GUIDENA: Jurnal Ilmu Pendidikan, Psikologi, Bimbingan dan Konseling, 3(1), 4249.

Kuswono, K. (2015). Kinerja Guru Sejarah Sma Di Kota Metro. Historia, 3(2), 91-98.

Mardiansyah, Y. (2013). “Pembuatan Modul Fisika Berbasis TIK Untuk Mengintegrasikan Nilai Pendidikan Karakter dalam Pembelajaran Siswa SMAN 10 Padang Kelas X Semester 1. Pillar of Physics Education, vol. 1. April 2013, hlm. 30-38.
Marzuki. (2010). Pembentukan kultur akhlak mulia di kalangan Mahasiswa UNY Melalui Pembelajaran PAl. Cakrawala Pendidikan, Februari 2010, Th. XXIX, No. 1. HIm. 120-133.

Mudlofir, A. (2011). Aplikasi Pengembangan Kurikulum Tingkat Satuan Pendidikan dan Bahan Ajar dalam Pendidikan Agama Islam. Jakarta: Raja Grafindo Persada.

Renier. G.J. (1997). Metode dan Manfaat Ilmu Sejarah. Yogyakarta: Pustaka Pelajar.

Sani, R.A. (2013). Inovasi Pembelajaran. Jakarta: Bumi Aksara.

Sartini. (2011). Guna Sejarah: Mengapa Harus Belajar Sejarah. Socio e-Kons Journal of The Counselling, Economic and History Education Vol. II No. $3 \mathrm{hlm}$. 59-67. Universitas Indraprasta.

Triatmanto. (2010). Tantangan Implementasi Pendidikan Karakter di Sekolah. Cakrawala Pendidikan, Mei 2010, Th. XXIX, Edisi Khusus Dies Natalis UNY. HIm. 187-203.

Von Ranke, L., \& Humboldt, W. (1973). The theory and practice of history. Bobbs-Merrill Company.

Winarni, S. (2013). Integrasi Pendidikan Karakter dalam Perkuliahan. Jurnal Pendidikan Karakter Tahun III, Nomor 1, Februari. hlm. 95-107. Yogyakarta: UNY.

Wineburg, S. (2006). Berpikir Historis: Memetakan Masa Depan, Mengajarkan Masa Lalu. Jakarta: YOI. 